\title{
Water balance of a Southern Moravian floodplain forest under natural and modified soil water regimes and its ecological consequences
}

\author{
Jan Čermák and Alois Prax \\ Institute of Forest Ecology, Mendel University of Agriculture and Forestry, Zemedelska 3, 61300 Brno, Czech Republic
}

(Received 10 April 2000; accepted 20 June 2000)

\begin{abstract}
Stand water balance was calculated in a floodplain forest in Southern Moravia. A model was applied to actual and theoretical scenarios of climate and soil water supply. Rooted and root-free soil volumes were considered separately because root development was poor for these trees. Input data, i.e., measured flows within the system including sap flow rate, characterize both the period of regular natural floods and period when floods were interrupted for over 20 years because of canalization of rivers in the region. Under non-limiting underground water supply, net precipitation supplied only about 50 and $25 \%$ of water for actual evapotranspiration, $E_{\mathrm{T}}$, under mild and dry weather, respectively, and the other 30 and $60 \%$ came from underground sources. The model also characterizes the theoretical situation of no underground water supply, when $E_{\mathrm{T}}$ may decrease significantly. An important limit for water supply to the trees may be the maximum hydraulic conductivity $K$, allowing horizontal transport in heavy soils, because a small decrease in soil water content $\left(2\right.$ to $4 \%_{\text {vol }}$ ) causes a large drop in $K$. $K$ may become supply-limiting before soil water potential becomes a limiting factor. Trees with smaller or damaged root systems or lower root/shoot ratio were especially threatened by drought even on relatively moist heavy soils.
\end{abstract}

floodplain forest / large trees / root systems / water balance / soil hydraulic conductivity / limiting water supply / Southern Moravia / modeling

Résumé - Bilan hydrique d'une forêt dans une plaine alluviale du Sud de la Moravie en conditions naturelles ou sous des régimes hydriques modifiés : ses conséquences écologiques. Le bilan hydrique a été calculé dans des peuplements situés dans une plaine alluviale du Sud de la Moravie. Un modèle a été appliqué à des scénarios actuels ou théoriques de climat et d'alimentation en eau. Les volumes de sol, avec et sans racines, ont été pris en compte séparément du fait que le développement racinaire de ces arbres était faible. Les valeurs entrées, par exemple les flux mesurés dans le système incluant le flux de sève, caractérisent l'ensemble des périodes, celles des inondations naturelles régulières et celles durant lesquelles les inondations furent interrompues pendant plus de 20 ans du fait de la canalisation des rivières de cette région. Sous conditions non limitatives d'alimentation en eau du sol, les précipitations nettes fournissent seulement environ 50 et $25 \%$ de l'eau pour l'évaporation réelle, $E_{\mathrm{T}}$, sous un temps moyen et sec, respectivement, et les autres 30 et $60 \%$ ont pour origine l'eau du sol. Le modèle caractérise aussi les situations théoriques d'une absence d'alimentation en eau provenant du sol, lorsque $E_{\mathrm{T}}$ peut décroître significativement. Un facteur limitant important pour l'alimentation en eau des arbres peut être le maximum de la conductivité hydraulique $K$, permettant un transport latéral dans les sols lourds. À cause de la faible diminution de la teneur en eau (2 à $4 \%$ vol $)$ cela provoque une forte chute dans la valeur de $K$. $K$ peut devenir facteur limitant de l'alimentation avant que le potentiel hydrique ne devienne le facteur limitant. Les arbres ayant un système racinaire réduit ou endommagé ou bien avec un rapport racine/pousse faible, étaient spécialement menacés par la sécheresse, même sur les sols lourds relativement humides.

plaine alluviale / gros arbres / systèmes racinaires / bilan hydrique / conductivité hydraulique du sol / alimentation en eau limitante / Sud de la Moravie / modélisation

\footnotetext{
* Correspondence and reprints

Fax: +42(0)5/4521-1422; e-mail: cermak@mendelu.cz
} 


\section{INTRODUCTION}

Important hydrological changes induced by water management policies including canalization of rivers occurred in southern Moravia in late seventies and eighties. This caused decreasing or complete cessation of floods in the region and decreased the level of underground water tables. This change has an impact on floodplain forests along the Dyje river, because the trees were originally adapted to high water tables and regular seasonal floods. There is concern that these forests (as the typical plant community of the region) may be threatened, and a need to understand which parameters of the changing environment or stand water balance may be critical for functional stability of forests and their survival $[21,23]$. In particular we consider the sufficiency of two sources of water, i.e., the amount of water coming from local precipitation and the amount from underground water supply (dependent on the water table in the near-by river) and the influence of different soil hydraulic properties $[2,48]$.

We tried to elucidate the questions through an analysis of stand water balance [1,24]. The water balance model was based especially on the quantitative knowledge of aboveground and underground structure of large trees in floodplain forests [5, $6645,46,47]$ and their seasonal transpiration measured at the experimental site $[11,12,16,34,35]$. Stand water balance was calculated for unit of stand area, but was scaled down to the fraction of stand area that belongs to a single model tree and other components of the system of proportional sizes. Long-term measurements allowed comparison of the original situation at the time of regular floods with actual and theoretical situations occurring under contrasting water supply after ceasing of floods. The study focused on describing the general approach, more detail analysis using different time steps and evaluating errors follows in subsequent studies.

\section{MATERIALS AND METHODS}

\subsection{Location, stand and the environmental conditions}

The experimental site is situated near the small town of Lednice in the southernmost part of Moravia (district Breclav) in the alluvium of the Dyje river (elevation of $160 \pm 1 \mathrm{~m}$ ). The site is classified as Ulmeto-fraxinetum carpineum, Rubus caesius L., Deschampsia cespitosa (L.) Beauv., Dactylis polygama (Horv.) Dom. and Viola sylvatica Fr. [46]. Local soils originated from sedimentation of materials during spring floods, which occurred almost every year up to 1972 . The 1.5 to 2 -m thick layer of soils of quaternary origin is characterized as semigley [33] or Fluvi-eutric gleysols - FAO 1970 [20] on medium heavy to heavy alluvial sediments. In general, such soils have poorly differentiated horizons, but vary slightly in their physical properties with depth and site as a result of variable conditions during their sedimentation [2]. Within the experimental site the soil properties were homogenous [26], although sedimentation of heavy alluvial layers occurs occasionally in rather small spots over the area $[29,37]$. These surface soils overlay an $8-\mathrm{m}$ thick layer of subsoil composed of gravel and sand sediments of quaternary origin laying above impermeable clay sediments of tertiary origin.

The forest stand was composed of oak (Quercus robur L., $78 \%$ of basal area), ash (Fraxinus excelsior $L$. and $F$. angustifolia Vahl., 18\%), lime (Tilia cordata L., 3\%) and other hardwood species (Acer campestre L., Populus alba L., Ulmus carpinifolia L., 1\%). The stand was planted in 1877; mean age of dominant trees was 95 years during the last regular floods in 1972, stand density $90 \%$ (when compared to model values of Forest Management Institute). The leaf area index was 5 for the tree layer and 2 for the shrub layer $[6,45,46,47]$. There were local groups of young ash and lime. The main shrub species of the undergrowth was Cornus sanguinea $L$.

Water balance in the soil-tree-atmosphere continuum was calculated from the transpiration (sap flow rate) data measured in average on six large trees at the experimental site during nine years over the period of 1972 to 1995 $[11,12,16,34,35]$. Data characterizing other terms in stand water balance (precipitation, interception, stem flow, soil water, soil evaporation, runoff) were estimated by other colleagues at the same site $[26,37,44$, where all the methodical details are given]. Data from the first period of measurement (1972-1974), characterized the state of almost undisturbed floodplain forest. Data obtained from the subsequent ten years characterized the transition period when the forest responded to gradually drying soils [12] and data from most recent years [16] corresponded to the situation after relative stabilization of soil water conditions.

\subsection{Size of components of the model}

A floodplain forest of unit area $A_{\text {stand }}$ (1 ha) was considered as a basis for modeling. To ease the description of stand structure all data were scaled down to a part of stand area corresponding to a single model tree $A_{\text {tree }}$ and its proportional surroundings (figure 1). $A_{\text {tree }}$ was derived from the ratio of biometric parameters of the model tree, particularly basal area weighted by tree height (i.e., timber 
volume $)$ of the model tree $\left(V_{\text {T.tree }}\right)$ and of the stand ( $\left.V_{\text {T.stand }}\right)$ at the area of $A_{\text {stand }}$

$$
A_{\text {tree }}=A_{\text {stand }}\left(V_{\text {T.tree }} / V_{\text {T.stand }}\right) \text {. }
$$

Stand area represented by the model tree, $A_{\text {tree }}$ (with corresponding radius of $r_{\text {tree }}$ ) is considered equal to the maximum possible area, that could be occupied by the tree

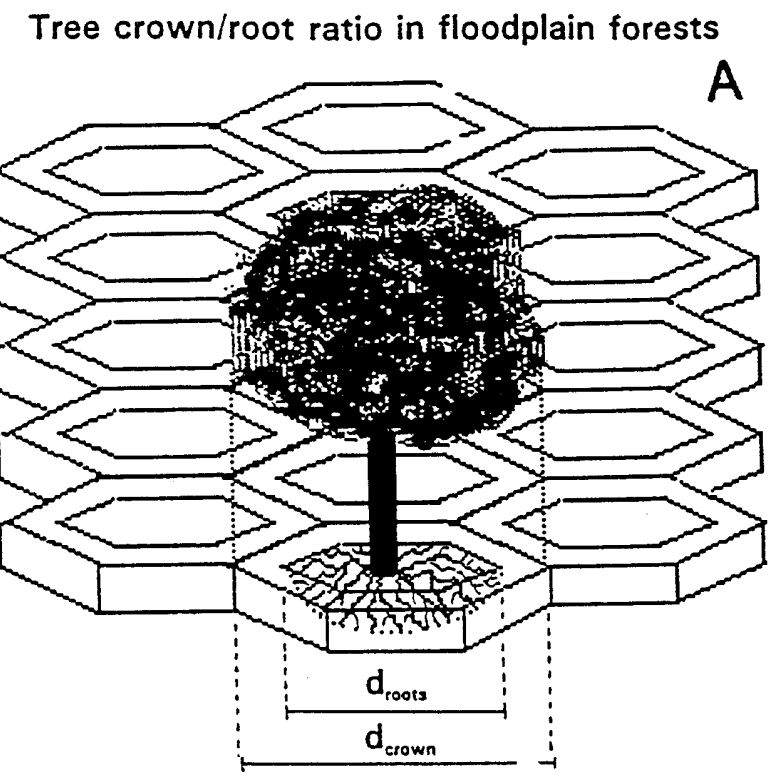

Soil water flows in the floodplain forest:
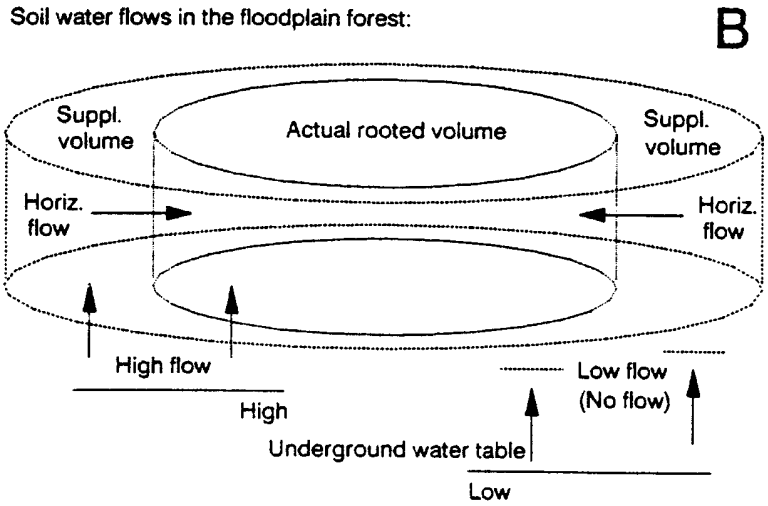

Figure 1. Spatial characteristics of Soil Plant Atmosphere Continuum (SPAC) in the floodplain forest, southern Moravia used in modeling stand water balance expressed proportionally for the single (mean) tree. Part A shows radii of the tree crown and of the root system, when projected on the ground correspond to defined stand areas. Space occupied by tree roots (the rooted volume of soil and corresponding projected area) is typically smaller than that of crowns in the floodplain forest. Supplementary space is the free volume in soils between individual main canopy trees which is not occupied by root systems of such trees. Part B shows water flows considered in the model. crown ground plan, $A_{\mathrm{ct}}{ }^{\max }$ or similarly by the ground plan of root systems, $A_{\mathrm{rt}}$ max , so that

$$
A_{\text {tree }}=A_{\mathrm{ct}}^{\max }=A_{\mathrm{rt}}^{\max } \text {. }
$$

The allometric relations of trees were calculated from biometric data given by [47], who analyzed both aboveground and underground systems of 15 large main canopy trees in the same stand and $[45,46]$ who analyzed shrub and herbaceous layer. Standard errors of the appropriate regressions were about $8 \%$ for aboveground parts of trees and 7 and 19\% for the depth and ground plan area of root systems. The biometric parameters of the model tree (table I) were derived using the quantile of total $[8,14]$, which emphasizes the importance of larger trees, instead of the simple arithmetic mean.

The rhizosphere was considered as a volume of soil occupied by root systems of trees (with corresponding root ground plan area). We distinguished the maximum rhizosphere of main canopy trees, $V_{\mathrm{rt}}^{\max }$, as the total volume of soil below 1 ha of stand area down to the observed maximum depth of root systems. This corresponds to maximum root ground plan area, $A_{\mathrm{rt}} \max$. The actual rhizosphere was that volume of soil, $V_{\mathrm{rt}}$ act (and corresponding actual root ground plan area, $A_{\mathrm{rt}}{ }^{\mathrm{act}}$ ), which was occupied by tree root systems estimated during excavation studies [47]. Volume of the supplementary rhizosphere $V_{\mathrm{rt}}^{\text {sup }}$ represents the volume of soil (and corresponding supplementary root ground plan area, $A_{\mathrm{rt}}^{\text {sup}}$ ) not directly occupied by tree roots, but serving as the additional water storage, which can be used by trees and where their roots could eventually grow.

The actual values of ground plan areas of crowns $\left(A_{\mathrm{ct}}{ }^{\text {act }}\right)$ were slightly smaller than the maximum possible because of gaps between crowns in the upper canopy. At the same level of the canopy, such gaps were caused by abrasion of buds, leaves and shoots during movement of crowns under strong winds [39]. However, no such gaps were apparent from the viewpoint of the entire stand, due

Table I. Main parameters of tree-soil system in the experimental stand of floodplain forest (site Horni les, forest district Breclav), southern Moravia (based on measurement by Vyskot, 1976) applied in the model calculated for the entire stand as represented by the model (mean) tree.

Variable Stand level Mean tree Proportion

Stand (crown) ground

plan area $\left(\mathrm{m}^{2}\right) \quad 10000$

Root ground plan area $\left(\mathrm{m}^{2}\right) \quad 5778$

Supplementary area $\left(\mathrm{m}^{2}\right)$

Mean (maximum) rooting

depth (m)

5778
4222

$\begin{array}{ll}90 & 100 \% \\ 52 & 58 \% \\ 38 & 42 \%\end{array}$

$1.48(1.75)$ 
to overlapping crowns of trees of different height creating multi-layer systems in the forest. That is why ground plan area of the model tree was taken as the proportion of the tree in the entire stand area $\left(A_{\mathrm{ct}}^{\mathrm{act}}=A_{\text {stand }}\right)$. The same was true considering understorey vegetation. In contrast and typically for the floodplain forest, significant gaps between individual, relatively small tree-root systems occurred in the soil [47].

$$
A_{\text {stand }}>A_{\mathrm{ct}}>A_{\mathrm{rt}} \text {. }
$$

Gaps in the soil between individual root systems were considered as certain root-free supplementary space (capable of supplying additional water) with corresponding supplementary ground plan areas of root systems (where roots can grow eventually), as

$$
A_{\mathrm{rt}}^{\text {sup }}=A_{\text {stand }}-A_{\mathrm{rt}}^{\text {act }} \text {. }
$$

Actual volume of soil containing the root systems, the volume of rhizosphere (analog to phyllosphere for stand canopy) of the model tree $\left(V_{\mathrm{rt}}^{\text {act }}\right)$ was taken as the volume below the actual root ground plan area $\left(A_{\mathrm{rt}}^{\text {act }}\right)$ down to the mean depth of root systems $\left(d_{\mathrm{rt}}\right): V_{\mathrm{rt}}^{\text {act }}=A_{\mathrm{rt}}^{\text {act }} d_{\mathrm{rt}}$. Similarly were considered also other volumes of soil, i.e., that corresponding to the actual crown ground plan area, $V_{\mathrm{ct}}^{\text {act }}=A_{\mathrm{ct}}^{\text {act }} d_{\mathrm{rt}}$ and that corresponding to the maximum crown ground plan area $\left(=\right.$ stand area), $V_{\text {stand }}=$ $A_{\text {stand }} d_{\mathrm{rt}}$. Ratio of all such volumes and thus also their calculation was similar as in the case of corresponding ground plan areas (see equation (4)). This considers the supplementary volume of rhizosphere $\left(V_{\mathrm{rt}}^{\text {sup }}\right)$, i.e., the total volume of soils outside the actual reach of root systems $\left(V_{\mathrm{rt}}^{\mathrm{act}}\right)$.

$$
V_{\mathrm{rt}}^{\text {sup }}=V_{\text {stand }}-V_{\mathrm{rt}}^{\text {act }} \text {. }
$$

\subsection{Calculating the water balance}

Stand water balance was calculated in mm or liters of water on the basis of known soil hydrological data [26, 37, 38] and known space, i.e., the size of compartments occupied by different components of the model [47]. The period one growing season (between leaf flushing and leaf fall), i.e., from May to October was considered according to the equation

$$
\begin{aligned}
E_{\text {act }}=E_{\mathrm{i}}+E_{\mathrm{T}}=E_{\mathrm{i}}+E_{\mathrm{Q}}+E_{\mathrm{res}}=d W+P_{\mathrm{n}} \\
+P_{\mathrm{sf}}+U(+H)-O
\end{aligned}
$$

where $E_{\text {act }}$ is the total actual evaporation from the stand, $E_{\mathrm{i}}$ is stand interception, $E_{\mathrm{T}}$ is evapotranspiration of the stand (Penman) and $E_{\mathrm{Q}}$ is transpiration of the tree layer in the stand. $E_{\text {res }}$ is so called "residual evapotranspiration", i.e., transpiration of the undergrowth, $E_{\mathrm{u}}$ (shrubs and herbaceous plants) and evaporation from the soil surface, $E_{\text {soil }} . d W$ is the difference in water storage in the soil between beginning and end of the study period, $P_{\mathrm{n}}$ is net precipitation (i.e., precipitation in the open, $P$ after subtracting the interception, $\left.E_{\mathrm{i}}\right) . P_{\text {sf }}$ is the amount of water coming with the stem flow, $U$ is the amount of water within soils obtained from the underground water table, $H$ is the amount of water which comes to the actual rhizosphere from the corresponding supplementary rhizosphere by the local horizontal transport. (This is possible in variants of the model considering smaller size of actual rhizosphere than the potential.) $O=$ $O_{\mathrm{h}}+O_{\mathrm{v}}+O_{\mathrm{s}}$ is the outflow from the system with components: horizontal, vertical and surface outflows.

Proportion of individual items of water balance, " $X$ " corresponding to different compartments (subsystems), was calculated from the values corresponding to the whole system (i.e., its maximum area, $A_{\text {stand }}$, see equation (1)) according to the ratio of root ground plan areas of trees and stand

$$
X_{\mathrm{rt}}=X_{\text {stand }}\left(A_{\mathrm{rt}} / A_{\text {stand }}\right)
$$

when values for corresponding compartments were calculated analogically as in equation (4). This was applied for $E_{\text {act }}, E_{\mathrm{i}}, P$ and $P_{\mathrm{n}}$. $E_{\text {res }}$ was calculated different ways for both subsystems as described further. Considering water storage terms, $d W$, similar calculations were made according to corresponding soil (= rhizosphere) volumes

$$
d W_{\mathrm{rt}}=d W_{\text {stand }}\left(V_{\mathrm{rt}} / V_{\text {stand }}\right)
$$

where values for corresponding subsystems were calculated analogically as in equation (5). Amount of water calculated in $\mathrm{m}^{3} \mathrm{ha}^{-1}$ in some equations was finally expressed in $\mathrm{mm}$.

Total actual evaporation from the stand of floodplain forest $\left(E_{\text {act }}\right)$ was calculated from the meteorological data as the potential evaporation ( $E_{\mathrm{pot}}$, Penman). This assumption was based on the previous study, when it was confirmed, that for the same year of study as analyzed here under non-limiting water supply both these quantities are equal for most of the growing season at the given stand [50]. Data applied for calculations were measured at the experimental site and partially those from the meteorological station of the University in Mendeleum, $2 \mathrm{~km}$ aerial distance from the experimental site.

\subsection{Estimation of individual terms of the equation}

Both precipitation in the open, $P$ and net precipitation, $P_{\mathrm{n}}$ were estimated directly in the experimental site on the basis of daily records of data over several years, [44]

$$
P_{\mathrm{n}}=P-E_{\mathrm{i}}
$$


where the interception was measured separately for the tree layer, $E_{\mathrm{it}}$ and the undergrowth layer, $E_{\mathrm{iu}}$ using altogether 32 meteorological rainfall troughs and gauges distributed along a transect line through the stand. Considering corresponding areas

$$
E_{\mathrm{i}}=E_{\mathrm{it}}+E_{\mathrm{iu}}
$$

stem-flow, $P_{\text {sf }}$ measured on a total of 33 trees was low in rough bark trees in the experimental stand, only about $0.5 \%$ of $P_{\mathrm{n}}$, so it was neglected in further calculations.

Evapotranspiration of the stand (i.e., for the maximum area, $\left.A_{\text {stand }}\right), E_{\mathrm{T}}$, was calculated as the difference between the total actual evaporation, $E_{\text {act }}$, and interception, $E_{\mathrm{i}}$

$$
E_{\mathrm{T}}=E_{\mathrm{act}}-E_{\mathrm{i}} \text {. }
$$

$E_{\mathrm{T}}$ was also considered equal to the sum of transpiration of the trees, $E_{\mathrm{Q}}$, the undergrowth, $E_{\mathrm{u}}$ and evaporation of soil, $E_{\text {soil }}$

$$
E_{\mathrm{T}}=E_{\mathrm{Q}}+E_{\mathrm{u}}+E_{\mathrm{soil}}=E_{\mathrm{Q}}+E_{\mathrm{res}} .
$$

According to the above equation the $E_{\mathrm{T}}$ was calculated for the area of actual rhizosphere, $A_{\mathrm{rt}}^{\text {act }}$. From that equation the "residual" evapotranspiration is clearly

$$
E_{\text {res }}=E_{\mathrm{u}}+E_{\text {soil }}
$$

or can be derived from the equation (12) as the difference between stand evapotranspiration $E_{\mathrm{T}}$ and transpiration of the trees $E_{\mathrm{Q}}$

$$
E_{\text {res }}=E_{\mathrm{T}}-E_{\mathrm{Q}} .
$$

In case of supplementary rhizosphere where no large trees were growing (and thus $E_{\mathrm{Q}}=0$ ), we calculated $E_{\mathrm{T}}=E_{\text {res }}$.

Transpiration of the tree layer (main canopy species), $E_{\mathrm{Q}}$ was estimated by direct measurement of sap flow in stems of sample trees. The trunk sector heat balance method with internal (direct electric) heating and sensing $[10,11,27]$ and compensating measurement of temperature [7] was applied. An average of 6 tall trees were

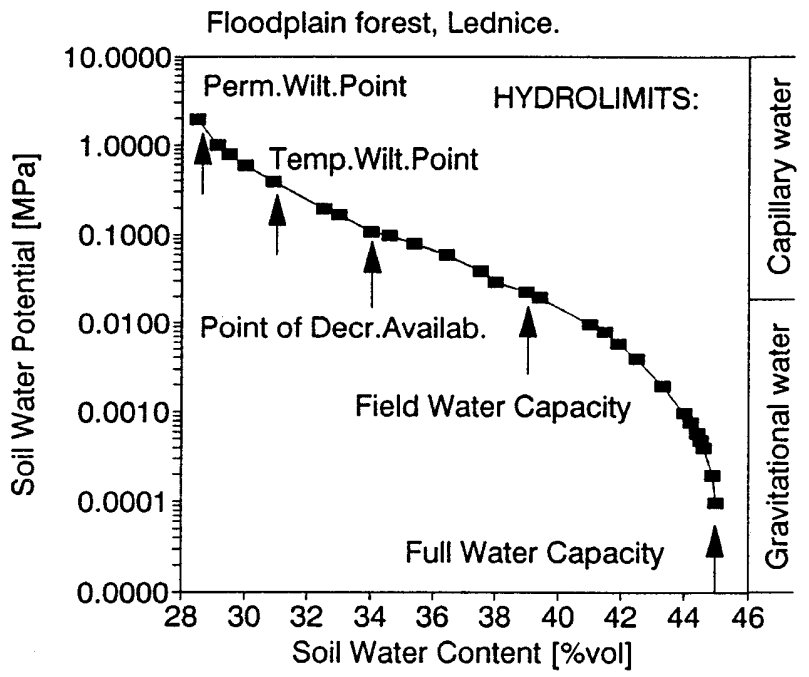

Figure 2. Soil water retention curve (relation of volumetric soil water content to water potential) in the floodplain forest, southern Moravia applied in modeling the stand water balance. Arrows indicate values corresponding to different soil hydrolimits. Soil water potential can be derived from water content by the relation: $y=2.04 \exp \left[0.86(x-28.4)^{0.7}\right] ; r^{2}=0.99$.

measured over the nine growing seasons between 1972 and $1995[11,12,16,34,35]$. Data from individual trees were scaled up to the stand according to their biometric parameters [5, 8].

Water consumed from the soil over the growing seasons $(d W)$ was taken as the difference between water storage at the beginning $\left(W_{1}\right)$ and at the end $\left(W_{2}\right)$ of study periods $\left(d W=W_{1}-W_{2}\right)$. This was estimated from long-term measurement of the level of underground water table and soil hydrolimits [26, 37, 38], derived from the relation of soil water $\left(\%_{\text {vol }}\right)$ on soil water potential (MPa or $\mathrm{pF}$ values) at the site (figure 2). Calculated values of soil hydrolimits (table II) are weighted

Table II. Main soil hydrolimits (full water capacity, field capacity - water retention, point of decreased availability and wilting points) and related soil parameters including soil hydraulic conductivity $\left(K_{\mathrm{w}}\right)$ and maximum possible horizontal soil water flow $\left(H_{\mathrm{w}}\right)$ in the floodplain forest (site Horni les, forest district Breclav), southern Moravia. Length of the growing season was considered 180 days.

\begin{tabular}{llcccccc}
\hline Soil hydrolimits & $\begin{array}{c}\text { Water availability } \\
(\mathrm{pF})\end{array}$ & $\begin{array}{c}\text { Water potential } \\
(\mathrm{pF})\end{array}$ & $\begin{array}{c}\text { Water content } \\
\left(\%_{\mathrm{vol}}\right)\end{array}$ & $\begin{array}{c}\text { Water storage } \\
(\mathrm{mm})\end{array}$ & $\begin{array}{c}\text { Hydraulic } \\
\text { conductivity } \\
\left(\mathrm{mm} \mathrm{d}^{-1}\right)\end{array}$ & $\begin{array}{c}\text { Maximum } \\
\text { horiz. Flow } \\
\left(\mathrm{mm} \mathrm{season}^{-1}\right)\end{array}$ \\
\hline Full water cap. & Over-watering & 0 & 0 & $45 \pm 3$ & 237 & 960 & 172106 \\
Field water cap. & Non-limiting & 2.2 & 0.02 & $39 \pm 3$ & 148 & 0.995 & 178.4 \\
Point of DWA & Low-stress & 3.3 & 0.2 & $34 \pm 2$ & 74 & 0.033 & 5.92 \\
Temporary wilt. p. & Moderate stress & 3.6 & 0.38 & $31 \pm 2$ & 34 & 0.0017 & 0.302 \\
Permanent wilt. p. & Severe stress & 4.18 & 1.5 & $28.5 \pm 2$ & 0 & $4.8 \times 10^{-0.6}$ & 0.000861 \\
\hline
\end{tabular}


averages considering five soil horizons, which cover the whole soil profile within the reach of tree root systems. In all water balance calculations we considered amounts of soil water available above two hydrolimits: (1) point of decreased water availability "pda" $\left(U_{\text {soil }}=-2\right.$ $\left.\times 10^{5} \mathrm{~Pa}\right)$ and $(2)$ wilting point "wp" $\left(U_{\text {soil }}=-15\right.$ $\left.\times 10^{5} \mathrm{~Pa}\right)$.

Amount of water within the soil profile of the system (i.e., the given size of the rhizosphere) obtained from underground water table, i.e.,the unknown item of the balance, $U$, was calculated from the main equation of the balance (equation 6) arranged into its simplified form. For calculations considering the size of the system as the "maximum rhizosphere", the equation was in the form

$$
U^{\max }=d W^{\max }+P_{\mathrm{n}}^{\max }-E_{\mathrm{T}}{ }^{\max } .
$$

When we considered the situation within the actual rhizosphere, also the item for local horizontal transport, $H$ was included. This considers the amount of water which flows out of the supplementary rhizosphere (with lower value of $E_{\mathrm{T}}$ ) into the actual rhizosphere (with higher value of $E_{\mathrm{T}}$ ), so that

$$
+H^{\text {act }}=-H^{\text {sup }} .
$$

For the actual rhizosphere we calculated

$$
\left(U^{\text {act }}+H^{\text {act }}\right)=d W^{\text {act }}+P_{\mathrm{n}}^{\text {act }}-E_{\mathrm{T}}{ }^{\text {act }}
$$

and similarly for the supplementary rhizosphere

$$
\left(U^{\text {sup }}+H^{\text {sup }}\right)=d W^{\text {sup }}+P_{\mathrm{n}}^{\text {sup }}-E_{\mathrm{T}}^{\text {sup }} .
$$

The amount of water representing the local horizontal transport, $H$, was considered as flowing from the supplementary to the actual rhizosphere (due to its larger water consumption) and was derived for the actual rhizosphere as positive value of

$$
+H_{\text {act }}=\left(U_{\text {act }}+H_{\text {act }}\right)-U_{\text {act }}
$$

and similarly for the supplementary rhizosphere as a negative value of

$$
-H_{\text {sup }}=\left(U_{\text {sup }}+H_{\text {sup }}\right)-U_{\text {sup }} .
$$

Surface outflow $\left(O_{\mathrm{s}}\right)$ was neglected during calculations, because the terrain was very flat and no such flow was observed (with exception of flooding water). Items of horizontal and vertical outflows $\left(O_{\mathrm{h}}\right.$ and $\left.O_{\mathrm{v}}\right)$ are included in items of soil water and underground water.

For modeled theoretical conditions of limited water supply, some terms of the water balance equation were calculated in a slightly different way. In particular, to calculate evapotranspiration under no underground water supply $\left(E_{\mathrm{T} \text {.noU }}\right)$, the originally calculated evapotranspiration with ample underground water $\left(E_{\mathrm{T} . \mathrm{aU}}\right)$ was reduced by subtracting the term of underground water flow (orig- inally $U_{\text {aU }} \gg 1$, reduced $U_{\text {noU }}=0$ ), but still contained the term for remaining horizontal water transport, $H$ i.e., equations (11) and (12) was replaced by

$$
E_{\mathrm{T} . \mathrm{noU}}=E_{\mathrm{T} . \mathrm{aU}}-U_{\mathrm{aU}}+H
$$

and equation (14) for tree transpiration $\left(E_{\mathrm{Q}}\right)$ was replaced by the equation considering that $E_{\mathrm{Q}}$ was lower when the underground water $U$ was cut off (i.e., similar behavior as observed in different species $-[4,17,18$, 19], thus

$$
E_{\mathrm{Q} . \mathrm{noU}}=E_{\mathrm{Q} . \mathrm{aU}}\left(E_{\mathrm{T} . \mathrm{noU}} / E_{\mathrm{T} . \mathrm{aU}}\right)
$$

where "nou" symbolizes the term for situation of no underground water and " underground water. All above terms were calculated separately for the entire stand and both compartments (rooted and supplementary volume) and hydrolimits of wilting point (wp) and point of decreased availability (pda) as in the previous case. Nevertheless the values for the point of decreased availability only were taken for further evaluation.

\subsection{Root area, soil hydraulic conductivity and conditions considered in the model}

Horizontal transport of soil water from the supplementary soil compartment to the soil compartment containing root systems was taken as through an area enveloping the actual root systems. In the model, this was taken as if the actual root system would grow in a cylindrical volume with the diameter of the actual root system (for the mean model tree, $r_{\text {r.act }}=4.07 \mathrm{~m}$ ). Considering the mean rooting depth (see table I), the horizontal enveloping area of the mentioned volume of the model tree, $A_{\text {r.pot }}$ was than taken $A_{\text {r.pot }}=37.9 \mathrm{~m}^{2}$ (area of the bottom of the cylindrical volume was not taken into account, since this was active only for conditions of non-limiting underground water supply).

Water balance was calculated for contrasting conditions of seasonal evaporation, relatively humid and dry years as characterized by their climatic water deficits $\left(d E_{\mathrm{pot}}=E_{\mathrm{pot}}-P\right)$, although always characterizing the dry or sub-humid climate and underground water table as dependent on distant precipitation and long-term climatic conditions. We distinguished contrasting "Mild" and "Dry" growing seasons characterized by water deficits of about 170 (150 to 200) and 380 (350 to 400$) \mathrm{mm}$, respectively. The water balance was calculated for conditions of ample water supply from underground water table and for a limited supply as if this source was theoretically unavailable. Soil water was considered sufficient after winter in some of above cases and as if it 


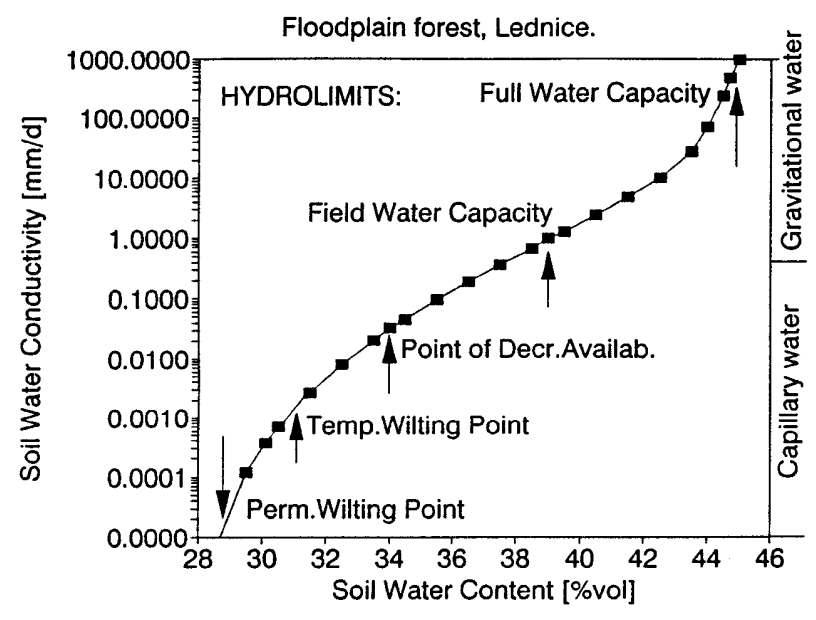

Figure 3. Relation of soil hydraulic conductivity to volumetric soil water content in the floodplain forest, southern Moravia applied in modeling the stand water balance. Arrows indicate values corresponding to different soil hydrolimits. Soil water conductivity can be derived from water content by the relation: $y=52.4 /(46.2-x)^{4.3} ; r^{2}=0.99$. (Data in the region of gravitational water may be by modified by movement of water in noncapillary, gravitational pores.)

would be partially exhausted (up to 50\%) after previous dry years. This way we obtained eight variants of water balance.

Limits to the horizontal water transport given by the soil hydraulic conductivity (figure 3 ), where the hydraulic gradient was caused by higher transpiration of trees in the rooted compartment compared to the supplementary one, were calculated from the equation

$$
H=K_{\mathrm{w}} A_{\text {r.pot }} d_{\text {season }} \text {. }
$$

The water balance was calculated with the step of one growing season, $d_{\text {season }}=180$ days (table II), and/or mean day of the season (i.e., the day with non-extreme environmental parameters).

\section{RESULTS AND DISCUSSION}

\subsection{Actual stand water balance under ample underground water supply}

Under non-limiting underground water supply, the level of underground water was within the upper layer of heavy soil, partially in direct contact with deeper parts of tree root systems. Input data on water balance character- ize the situation to which the floodplain forest was adapted in long-term (for several tens of years) and which was actually measured for several years under conditions of last regular natural floods in the region [11, 35]. Under such conditions, water use of the floodplain forest was similar to other highly transpiring mature forests as e.g., beech, but lower than in e.g. black alder growing under non-limiting water supply in years with high radiation input, which the authors [22] explain by a lower capacity of stomatal regulation in alder.

Under mild weather conditions (with the climatic water deficit of only $170 \mathrm{~mm}$ ) seasonal transpiration of main canopy trees, $E_{\mathrm{Q}}$ and actual evapotranspiration, $E_{\text {T.act }}$ were relatively low (261 and $338 \mathrm{~mm}$, respectively i.e., about $60 \%$ of that under dry years). This was due to lower potential evapotranspiration and more frequent occurrence of rainy and foggy days with higher interception (table III). Considering possible sources of available water within the entire soil-plant-atmosphere continuum of water flows (figure 4A), net precipitation itself was sufficient to cover completely the transpiration of main canopy trees and over $80 \%$ of actual evapotranspiration. Only a small fraction of water from underground water table and from soil storage, (97 and $74 \mathrm{~mm}$, respectively) was needed to supply the actual evapotranspiration (i.e., $29 \%$ and $22 \%$ of $E_{\text {T.act }}$ ). This provided that trees had access to about $100 \mathrm{~mm}$ of water from supplementary soil volume outside of the direct reach of tree root systems. Soil water content and related hydraulic conductivity remained high enough to allow for sufficient horizontal transport (also about $100 \mathrm{~mm}$ over the period under study) of water from supplementary soil volume into actually rooted volume of soil. The corresponding soil water content at this conductivity is lower than field water capacity (around $38 \%$ vol ) and records of soil moisture showed, that this situation really exists in long-term [37]. Theoretical exhausting of $50 \%$ vol of internal soil water storage (what simulated some drought in previous years) showed no significant effect (see table III). There is clearly no danger, that trees would suffer drought under such conditions.

Under dry weather conditions (characterized by a climatic water deficit of $380 \mathrm{~mm}$ ) seasonal $E_{\mathrm{Q}}$ and $E_{\mathrm{T} \text {.act }}$ was substantially higher (434 and $509 \mathrm{~mm}$, respectively). Lower precipitation (even if also under lower interception) could supply only about 42 and $36 \%$ for $E_{\mathrm{O}}$ and $E_{\text {T.act }}$, respectively, of the required water (figure $4 B$, see table III). Requirements for underground water supply increased about three times, up to $309 \mathrm{~mm}$ when considering amount of water up to the hydrolimit of point of decreased availability, thus underground water supplied most of the evaporated water (71 and $61 \%$ for tree transpiration and potential evapotranspiration, respectively). 
Table III. Main items of water balance (in mm) in the floodplain forest (site Horni les, forest district Breclav), southern Moravia under actually measured ample (non-limiting) water supply and under modelled no underground water supply for different weather and soil water storage conditions.

\begin{tabular}{|c|c|c|c|c|c|c|c|c|c|c|}
\hline \multirow{2}{*}{\multicolumn{2}{|c|}{ Variable }} & \multirow{3}{*}{$\begin{array}{r}\text { Underground water: } \\
\text { Soil water storage: } \\
\text { Weather: }\end{array}$} & \multicolumn{4}{|c|}{ Ample } & \multicolumn{4}{|c|}{ No } \\
\hline & & & \multicolumn{2}{|c|}{ Saturated } & \multicolumn{2}{|c|}{ Exhausted } & \multicolumn{2}{|c|}{ Saturated } & \multicolumn{2}{|c|}{ Exhausted } \\
\hline & & & Dry & Mild & Dry & Mild & Dry & Mild & Dry & Mild \\
\hline \multicolumn{11}{|c|}{ Compartment: Stand total } \\
\hline$E_{\text {pot }}$ & \multicolumn{2}{|c|}{ Potential evapotranspiration } & 567 & 446 & 567 & 446 & 567 & 446 & 567 & 446 \\
\hline$E_{\text {act }}$ & \multicolumn{2}{|c|}{ Actual evaporation } & 567 & 446 & 567 & 446 & 258 & 349 & 221 & 312 \\
\hline$P$ & \multicolumn{2}{|c|}{ Precipitation above stand } & 184 & 275 & 184 & 275 & 184 & 275 & 184 & 275 \\
\hline$P_{\mathrm{n}}$ & \multicolumn{2}{|c|}{ Net precipitation } & 126 & 167 & 126 & 167 & 126 & 167 & 126 & 167 \\
\hline$E_{\mathrm{it}}$ & \multicolumn{2}{|c|}{ Interception (tree layer) } & 47 & 75 & 47 & 75 & 47 & 75 & 47 & 75 \\
\hline$E_{\mathrm{iu}}$ & \multicolumn{2}{|c|}{ Interception (understorey) } & 11 & 33 & 11 & 33 & 11 & 33 & 11 & 33 \\
\hline$E_{\mathrm{i}}$ & \multicolumn{2}{|c|}{ Interception (total) } & 58 & 108 & 58 & 108 & 58 & 108 & 58 & 108 \\
\hline$E_{\mathrm{T}}$ & \multicolumn{2}{|c|}{ Actual evapotranspiration } & 509 & 338 & 509 & 338 & 200 & 241 & 163 & 204 \\
\hline$E_{\text {res }}$ & \multicolumn{2}{|c|}{ Evapotransp.(understorey+soil) } & 75 & 77 & 75 & 77 & 29 & 55 & 24 & 47 \\
\hline$E_{\mathrm{Q}}$ & \multicolumn{2}{|c|}{ Tree transpiration } & 434 & 261 & 434 & 261 & 171 & 186 & 139 & 157 \\
\hline$d W$ & \multicolumn{2}{|c|}{ Soil water storage } & 74 & 74 & 37 & 37 & 74 & 74 & 37 & 37 \\
\hline$U$ & \multicolumn{2}{|c|}{ Underground water supply } & -309 & -97 & -346 & -134 & 0 & 0 & 0 & 0 \\
\hline
\end{tabular}

Compartment: Actual rooted volume (rhizosphere)

\begin{tabular}{|c|c|c|c|c|c|c|c|c|c|}
\hline${ }_{\mathrm{r}} E_{\mathrm{pot}}$ & Potential evapotranspiration & 328 & 257 & 328 & 257 & 328 & 257 & 328 & 257 \\
\hline${ }_{E_{\text {act }}^{\mathrm{r}}}^{\mathrm{z} o t}$ & Actual evaporation & 511 & 367 & 511 & 367 & 221 & 280 & 186 & 246 \\
\hline${ }_{P}^{\mathrm{r}^{\mathrm{a}}}$ & Precipitation above stand & 106 & 159 & 106 & 159 & 106 & 159 & 106 & 159 \\
\hline${ }_{\mathrm{r}}^{\mathrm{r}} P_{\mathrm{n}}$ & Net precipitation & 73 & 96 & 73 & 96 & 73 & 96 & 73 & 96 \\
\hline${ }_{\mathrm{r}}^{\mathrm{r}} E_{\mathrm{it}}$ & Interception (tree layer) & 27 & 43 & 27 & 43 & 27 & 43 & 27 & 43 \\
\hline${ }_{\mathrm{r}} E_{\mathrm{iu}}$ & Interception (understorey) & 6 & 19 & 6 & 19 & 6 & 19 & 6 & 19 \\
\hline${ }_{\mathrm{r}} E_{\mathrm{i}}$ & Interception (total) & 34 & 62 & 34 & 62 & 34 & 62 & 34 & 62 \\
\hline${ }_{\mathrm{r}}^{\mathrm{r}} E_{\mathrm{T}}$ & Actual evapotranspiration & 478 & 305 & 478 & 305 & 188 & 218 & 153 & 184 \\
\hline${ }_{\mathrm{r}}^{\mathrm{r}} E_{\mathrm{res}}$ & Evapotransp.(understorey+soil) & 43 & 45 & 43 & 45 & 17 & 32 & 14 & 27 \\
\hline$E_{\mathrm{Q}}$ & Tree transpiration & 434 & 261 & 434 & 261 & 171 & 186 & 139 & 157 \\
\hline$d W$ & Soil water storage & 43 & 43 & 21 & 21 & 43 & 43 & 21 & 21 \\
\hline${ }_{\mathrm{r}} U$ & Underground water supply & -179 & -56 & -200 & -77 & 0 & 0 & 0 & 0 \\
\hline${ }_{\mathrm{r}} H$ & Horizontal flow & -183 & -110 & -183 & -110 & -72 & -78 & -59 & -66 \\
\hline
\end{tabular}

Compartment: Root-free (supplementary) volume

\begin{tabular}{|c|c|c|c|c|c|c|c|c|c|}
\hline${ }_{\mathrm{s}} E_{\mathrm{pot}}$ & Potential evapotranspiration & 239 & 188 & 239 & 188 & 239 & 188 & 239 & 188 \\
\hline${ }_{\mathrm{s}} E_{\mathrm{act}}^{\mathrm{pot}}$ & Actual evaporation & 56 & 78 & 56 & 78 & 37 & 69 & 35 & 65 \\
\hline${ }_{\mathrm{s}} P$ & Precipitation above stand & 78 & 116 & 78 & 116 & 78 & 116 & 78 & 116 \\
\hline$P_{\mathrm{n}}$ & Net precipitation & 53 & 71 & 53 & 71 & 53 & 71 & 53 & 71 \\
\hline$E_{\mathrm{it}}$ & Interception (tree layer) & 20 & 32 & 20 & 32 & 20 & 32 & 20 & 32 \\
\hline$E_{\mathrm{iu}}^{\mathrm{u}}$ & Interception (understorey) & 5 & 14 & 5 & 14 & 5 & 14 & 5 & 14 \\
\hline$E_{\mathrm{i}}$ & Interception (total) & 24 & 45 & 24 & 45 & 24 & 45 & 24 & 45 \\
\hline${ }_{\mathrm{s}} E_{\mathrm{T}}$ & Actual evapotranspiration & 31 & 33 & 31 & 33 & 12 & 23 & 10 & 20 \\
\hline${ }_{\mathrm{s}}^{\mathrm{s}} E_{\mathrm{res}}$ & Evapotransp.(understorey+soil) & 31 & 33 & 31 & 33 & 12 & 23 & 10 & 20 \\
\hline$E_{\mathrm{O}}$ & Tree transpiration & 0 & 0 & 0 & 0 & 0 & 0 & 0 & 0 \\
\hline$d W$ & Soil water storage & 31 & 31 & 16 & 16 & 31 & 31 & 16 & 16 \\
\hline${ }_{\mathrm{s}} U$ & Underground water supply & -130 & -41 & -146 & -57 & 0 & 0 & 0 & 0 \\
\hline${ }_{\mathrm{s}} H$ & Horizontal flow & 183 & 110 & 183 & 110 & 72 & 78 & 59 & 66 \\
\hline \multicolumn{10}{|c|}{ Resulting flows: Stand total } \\
\hline \multirow{4}{*}{\multicolumn{2}{|c|}{$\begin{array}{l}\text { Total flow from underground } \\
\text { Total horizontal flow } \\
\text { Total flow from outside } \\
\text { Missing water due to limiting } \mathrm{K}_{\max }\end{array}$}} & -309 & -97 & -346 & -134 & 0 & 0 & 0 & 0 \\
\hline & & 183 & 110 & 183 & 110 & 72 & 78 & 59 & 66 \\
\hline & & 0 & 0 & 0 & 0 & 0 & 0 & 0 & 0 \\
\hline & & -175 & -102 & -175 & -102 & -64 & -70 & -51 & -58 \\
\hline
\end{tabular}




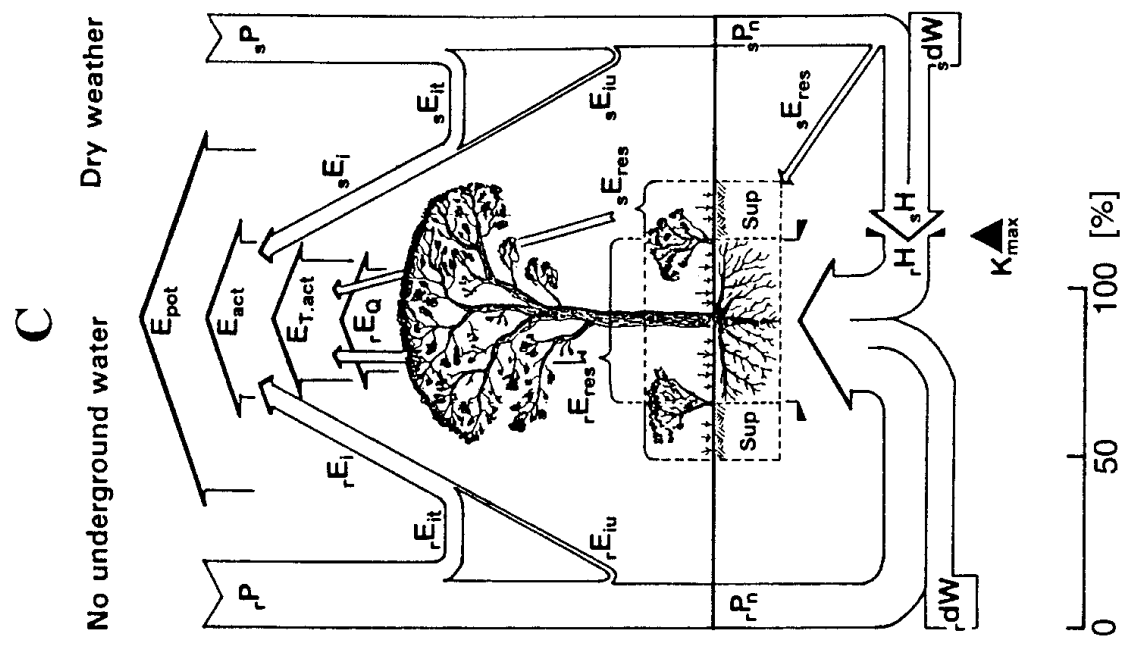

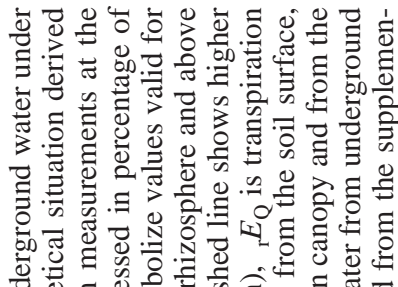

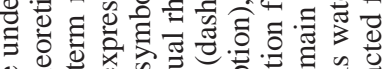

은

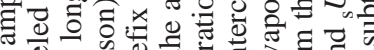

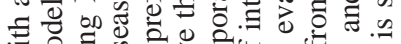

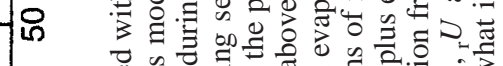

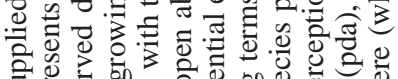

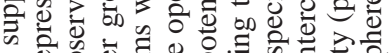

की

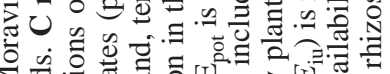

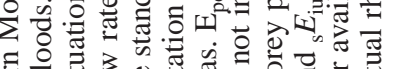

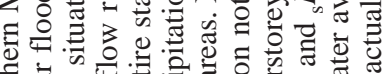

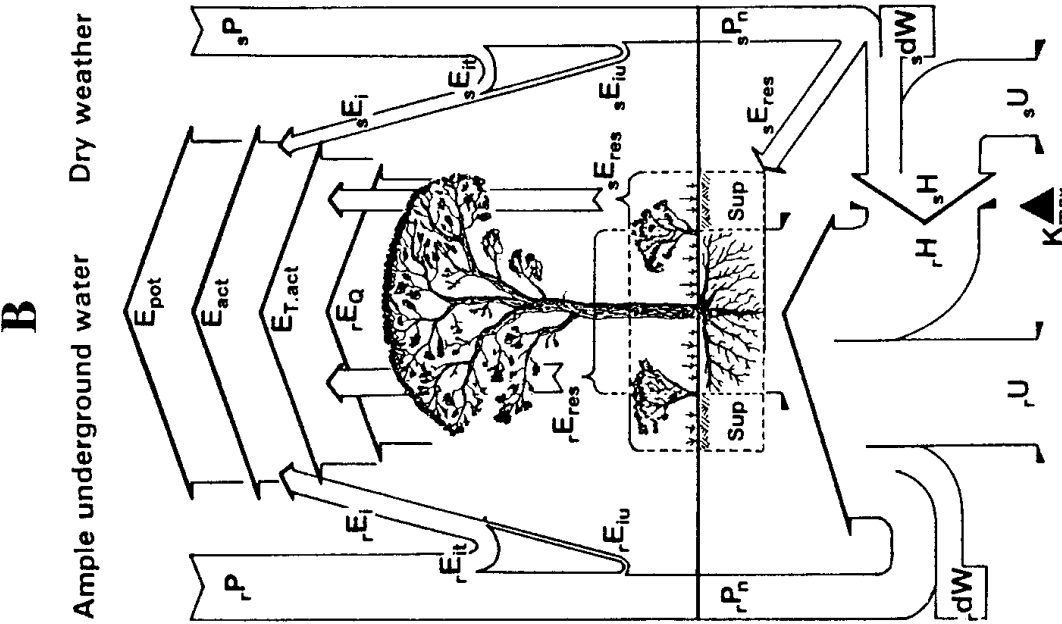

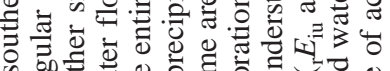

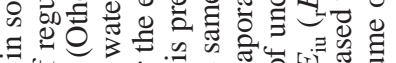

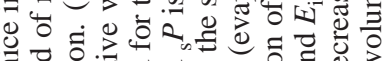

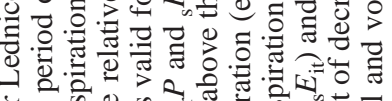

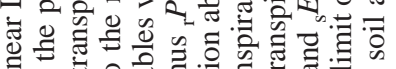

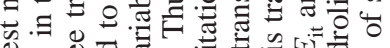

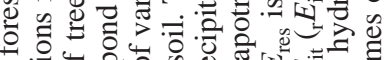

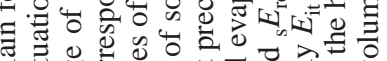

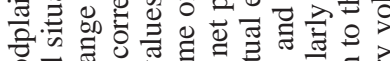

吨

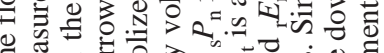

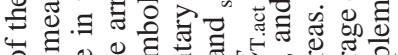

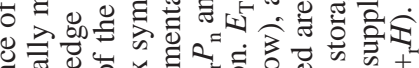

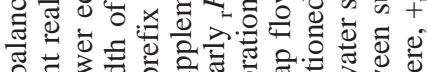

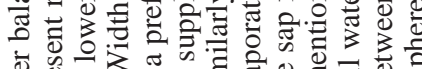

एक

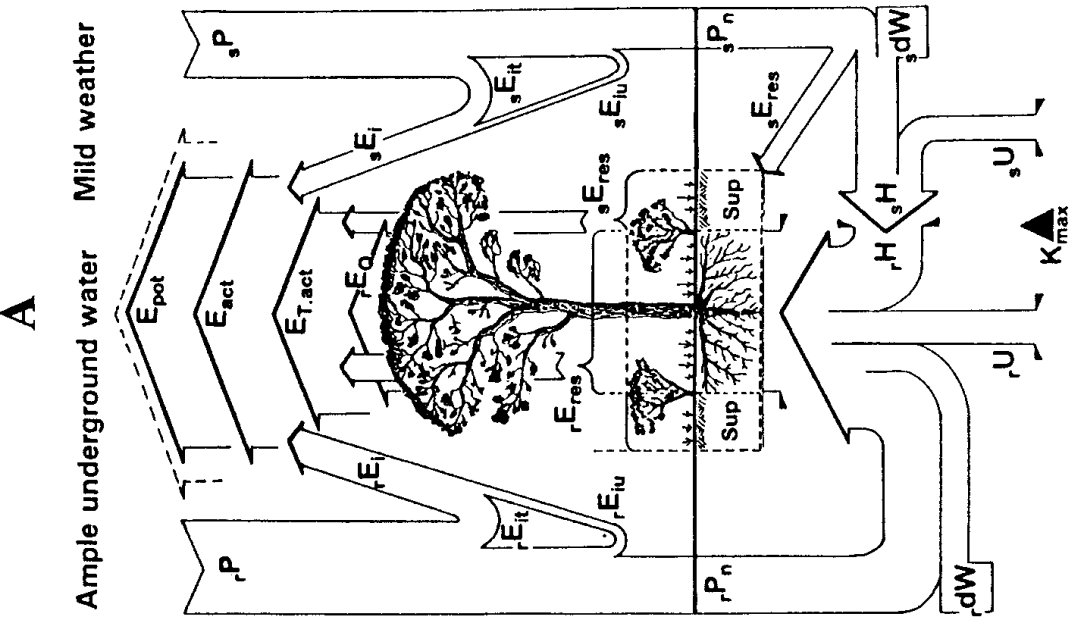

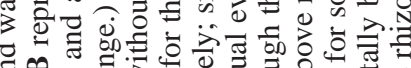

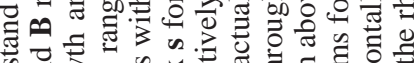

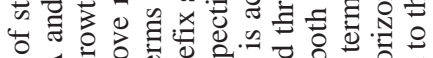

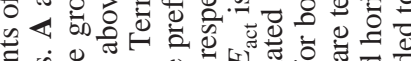

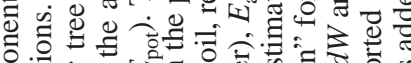

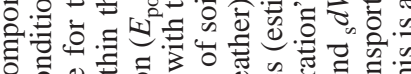

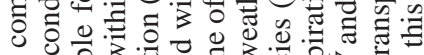

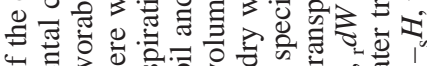

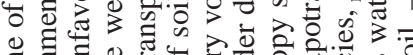

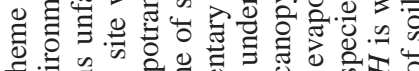

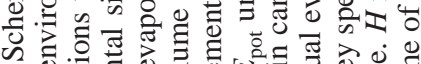

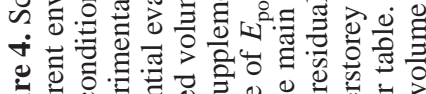

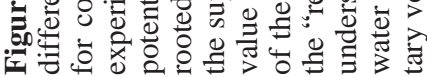


Requirements for horizontal transport in soils increased to over $180 \mathrm{~mm}$, i.e., by about $2 / 3$ compared to the situation under mild weather conditions. Internal soil water storage remained less important in this case, since it represents only $15 \%$ of required water (see table III). Soil hydraulic conductivity allowing for transport of required amount of water is high enough only under relatively high soil water content close to the field water capacity (about $39 \%_{\text {vol }}$ ). Any decrease of soil water content below this value may cause, as hydraulic conductivity becomes critical for the water supply (see table II), what may at least partially happen under typical weather especially in the second half of growing seasons [37]. Having in mind individual variation of tree root system structure and soil conditions within stands, it can be expected, that small portions of main canopy trees may suffer drought $[4,17$, $18,19]$.

\subsection{Theoretical stand water balance under no underground water supply}

If the level of underground water fell a few decimeters below the layer of heavy soils where all roots of trees are located into the layer of sandy gravel, water supply from this underground source would be interrupted due to very low capillary rise (roots could not adapt themselves fast enough). This is characterized by the theoretically derived model scenarios. We consider that water consumption changed there, while interception, soil water storage and potential evapotranspiration were supposed to be the same as we actually found. In fact, the model scenarios can occur in the given region in reality, especially in rather frequent places where in addition to cessation of floods the underground water was lowered due to its extraction from sandy-gravel aquifers, to be applied as drinking water for local needs [38].

Without an underground water supply, the entire treesoil system adapted to different conditions would not have sufficient water to keep transpiration as high as under ample supply under the same weather conditions. Stand evapotranspiration must decrease down at least to the value, that would assure that all the water required for evapotranspiration will be present in the system (missing water in the rooted volume of soil would be equal to the water present in the supplementary volume of soil). A model situation without underground water is theoretical only; however, in some years following the cessation of floods after watershed management measures in the region accompanied by the regulation of river beds, such situation is likely to occur in reality [16].

According to the model, under theoretical conditions of no underground water but mild weather (and still remaining higher water content in soils) transpiration of main canopy trees and actual evapotranspiration would decrease down to about 186 and $241 \mathrm{~mm}$, respectively, i.e., to $70 \%$ of that under ample underground water (see table III). Net precipitation itself could almost meet all the transpiration requirements of main canopy trees (90\%) and somewhat less considering the actual evapotranspiration of the stand (69\%). Only about $78 \mathrm{~mm}$, i.e.,

Table IV. Fractions of water in the calculated water balance of the floodplain forest (site Horni les, forest district Breclav), southern Moravia, coming from different sources.

\begin{tabular}{|c|c|c|c|c|c|c|c|c|c|}
\hline & \multirow{3}{*}{$\begin{array}{l}\text { Underground water: } \\
\text { Soil water storage: } \\
\text { Weather: }\end{array}$} & \multicolumn{4}{|c|}{ Ample } & \multicolumn{4}{|c|}{ No } \\
\hline & & \multicolumn{2}{|c|}{ Saturated } & \multicolumn{2}{|c|}{ Exhausted } & \multicolumn{2}{|c|}{ Saturated } & \multicolumn{2}{|c|}{ Exhausted } \\
\hline & & Dry & Mild & Dry & Mild & Dry & Mild & Dry & Mild \\
\hline \multicolumn{10}{|c|}{ Proportion of large tree transpiration $\left(\% E_{\mathrm{Q}}\right)$} \\
\hline$P$ & Precipitation above stand & 42 & 105 & 42 & 105 & 108 & 148 & 132 & 175 \\
\hline$P_{\mathrm{n}}$ & Net precipitation & 29 & 64 & 29 & 64 & 74 & 90 & 91 & 106 \\
\hline$U^{n}$ & Underground water supply & -71 & -37 & -80 & -51 & 0 & 0 & 0 & 0 \\
\hline$d W$ & Soil water storage & 17 & 28 & 9 & 14 & 43 & 40 & 27 & 24 \\
\hline$H$ & Horizontal flow & 42 & 42 & 42 & 42 & 42 & 42 & 42 & 42 \\
\hline \multicolumn{10}{|c|}{ Proportion of stand evapotranspirat. ( $\left.\% E_{\mathrm{T}}\right)$} \\
\hline$P$ & Precipitation above stand & 36 & 81 & 36 & 81 & 92 & 114 & 113 & 135 \\
\hline$P_{\mathrm{n}}$ & Net precipitation & 25 & 49 & 25 & 49 & 63 & 69 & 77 & 82 \\
\hline$U$ & Underground water supply & -61 & -29 & -68 & -40 & 0 & 0 & 0 & 0 \\
\hline$d W$ & Soil water storage & 15 & 22 & 7 & 11 & 37 & 31 & 23 & 18 \\
\hline$H$ & Horizontal flow & 36 & 33 & 36 & 33 & 36 & 33 & 36 & 33 \\
\hline
\end{tabular}


$32 \%$ of the water needed for evapotranspiration should be supplied from the supplementary soil volume by the horizontal water transport, which would be possible under a given soil hydraulic conductivity (see tables II and $I V$ ). The majority of main canopy trees probably will not suffer significantly due to limited underground water supply, since transpiration would be kept low due to low evaporation demands.

Without an underground water supply but high evaporation demands of dry weather and corresponding partially exhausted soil water storage, stand water consumption would be lower by the amount of water equal to that supplied from underground sources (see table III). Scheme of flows considered in this version of water balance is shown on (figure 4C). Transpiration of main canopy trees and actual stand evapotranspiration according to the model would theoretically decrease down to about 140 and $160 \mathrm{~mm}$ (for "pda" and "wp" conditions, respectively), i.e., down to almost $1 / 3$ compared to that under ample underground water and the same weather conditions. Calculated water balance showed, that net precipitation itself would supply the lowered transpiration of main canopy trees in a similar proportion as under mild weather. Only about 37 and 23\% from under originally saturated and partially exhausted soil water, respectively of the required water for evapotranspiration could be supplied from soil water storage and about 60 to $70 \mathrm{~mm}$ (i.e., $36 \%$ of corresponding actual evapotranspiration) from supplementary soil volume under dry weather (see table III). All situations which occurred during long-term measurements at the experimental site $[11,12,16,34,35,36,50]$ were within the above range.

\subsection{Hydraulic conductivity and limiting horizontal flows}

Values of soil hydraulic conductivity, $K_{\mathrm{w}}$ for different hydrolimits (see figure 3) and corresponding maximum possible horizontal flow, $H_{\max }$ calculated for the whole growing season (see table II) were important in the calculated stand water balance as discussed in the previous chapter. Under ample underground water supply and mild weather conditions the actual hydraulic conductivity of soil is higher than required and represents no limit to plant water supply. However under dry weather, even with ample underground water, the hydraulic conductivity may become limiting even under relatively high soil moisture (figure 5). In the given example of stand water balance this limit occurred when soil water content decreased to the field water capacity $\left( \pm 1 \%_{\text {vol }}\right)$, i.e., less water will be available for plants than that calculated in the model considering soil water down to the usual hydrolimit of decreased availability. Supposing evapo-

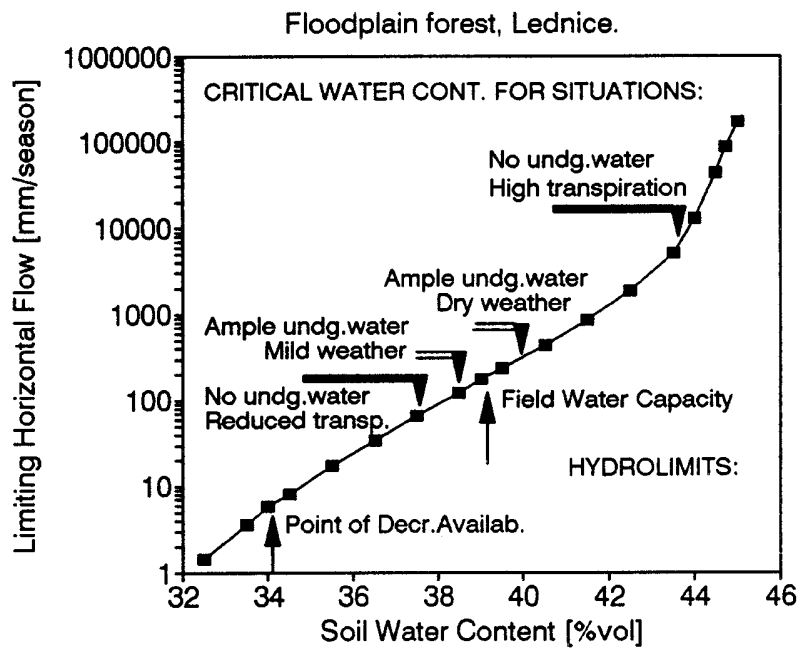

Figure 5. Relation of limiting horizontal flow of water resulting from soil hydraulic conductivity for a model soil-tree system in the floodplain forest, southern Moravia. Lower arrows indicate values corresponding to most important soil hydrolimits. Upper arrows indicate values critical for trees under different environmental conditions.

transpiration of the forest stand remained as high without underground water as under ample underground water, then the required soil hydraulic conductivity should be about two orders higher compared to that corresponding to field water capacity. This is not likely to occur under such conditions. Even if the stand evapotranspiration decreased down to the value, that would assure that all the water required for evapotranspiration will be theoretically available in the entire system (missing water in the rooted volume of soil would be equal to the water present in the supplementary volume of soil), the required hydraulic conductivity would be about an order higher compared to actual one considered for the modeled conditions.

Soil hydraulic conductivity is a physical property of crucial importance for groundwater flows in different scales [49]. Our results mean, that in reality under slight decrease of soil water content (by about 2 to $4 \%_{\mathrm{vol}}$ ), the water supply will be still more limited than shown in the given model. Particular figures valid for a period of one growing season may differ for shorter periods of time, when the mentioned limits will be still more important. Fortunately large buffering capacity of heavy soils smoothed excessive changes in its properties [31, 40], which supports our conclusions. In general the results show, that where using applied hydraulic parameters of soils, the soil water content as well as corresponding soil 
water potential do not represent sufficient information for correct estimation the plant water supply. The inevitable third soil parameter which is important especially in heavy soils is the hydraulic conductivity. This parameter is somewhat tricky, since it may become severely limiting under seemingly sufficient soil water, which is significantly higher than that under which the bulk soil water potential might become limiting. It also may become important within much lower range of changes in corresponding soil water contents.

Limits of hydraulic conductivity for soil water supply in heavy soils may occur in large scales as well as in the very local scales (down to individual trees or roots). Soil water content cannot equilibrate between distant places fast enough and thus significant differences may persist there. This was observed e.g., in stands of large beech trees growing on heavy soils [15] or on similar soils near roots of maple trees growing in the city [18].

\subsection{Limitations of the present model and possible improvements}

The time step applied in the model is longer than that usually taking place under natural conditions (when soil water can change faster after rain or during severe drought). However the above described situations were aimed to demonstrate the phenomena which may play important role for tree survival under conditions of seemingly sufficient soil moisture rather than to describe a particular year or different time steps of water balance (which is the task of following studies). Situation can be even more severe under natural conditions, especially if considering, that substantial changes in transpiration, which is followed by corresponding changes of sap flow and absorption of water by roots can proceed very fast in study species - within minutes or even shorter time intervals $-[13,27,32]$ and similarly fast can probably be also changes in soil moisture within a boundary layer of soil adjacent to root surfaces. These questions are under further studies now.

Individual figures presented in the results are valid for soil properties present in the given forest stand characterized as the defined forest type. (1) Extrapolation of the model to other sites is possible only provided all necessary quantitative input soil parameters for each site are available, such as described by Prax [37] in the floodplain of Dyje and Moravia rivers in Southern Moravia. (2) In order to get still more accurate figures on the actual limits of plant water supply, a shorter time step than one growing season (such as months, days or even hours) could be applied (as in our following studies). It is clear that the soil limits will be more strict under such conditions (e.g., when maximum daily transpiration and corresponding hydraulic gradients may be about twice as high as seasonal mean daily transpiration under fine weather). However, to validate this by the experimental data would require much more instrumentation (direct measurement of gradients near all roots, etc.) than was available at the beginning of studies years ago. (3) Trees may gradually adapt their root structure to the new situation when continuously changing the soil water supply. Such adaptations will differ in different species and trees of different age and social position - this all will be reflected by tree behavior in long-term.

\subsection{Soil water supply in woody species with different root systems}

The actual size of the tree-root system applied in the model corresponded to the situation, when trees were adapted in long-term to the supra-optimal water supply under high water table and occurrence of regular floods. Under such situations, some species as oaks develop relatively small root systems - projected area of root systems is smaller compared to that of crowns - [25]. With limitations to the water supply after water management measures in the region we may expect gradual adaptation of root systems, i.e., increase of root length [28, 30, 41, 43] but only after years; old age may limit adaptive capabilities of large trees [21, 23], especially in heavy soils [48].

Structural prerequisites of trees seem to be important for their survival and/or their mortality. Considering the short-term responses, individual trees with already developed deeper and/or more extensive root systems are in a more favorable situation compared to trees with less developed roots. Most large oaks and ashes in the experimental plot have well developed roots, however in trees of both species growing in slightly suppressed or intermediate social positions relatively to large trees, poorer development of root systems was observed [47]. This is best visible on the root/shoot ratio calculated for the whole tree level as the ratio of "Root Enveloping Area" (applied in this study) to sunlit leaf area or "Solar Equivalent Leaf Area" sensu Čermák [5] at the same stand. Trees with low root/shoot ratio seems to be especially endangered by drought, because their crowns are still reaching the main canopy and requiring more water for transpiration which less developed roots cannot supply. Minimum root/shoot ratio corresponded to the maximum of tree mortality recorded over the last 20 years at the given stand (figure 6).

Shallow root systems were observed in shrubs e.g., frequent Cornus sanguinea at the same site [45]. This 
suggests that they might decline first in case of severe drought (what we observed in reality at the site) since they can be easily over-competed for water by large trees. This has been found also elsewhere in similar conditions [15].

\subsection{Soil water supply, stand density and health state of trees}

Significant lowering the water supply for transpiration which leads to decreasing the leaf and root water potentials may reach a level under which the resistance of roots against fungi is impaired, since some of such pathogens can grow better under lower potentials than higher plants. Drought can break the roots physical and biochemical barriers or increasing the disease susceptibility as a predisposition of infections [3, 42]. This secondary impact of drought stress was confirmed by the phytopathologic search in the experimental stand, where occurrence of different fungi species (e.g., Phellinus robustus (P.Karst) Bourd.et Galz., Armillaria mellea (Vahl.ex Fr.) Kumm. and Inonotus dryophilus (Berk.) Murr.) increased dramatically after partial drought compared to the original status during regular floods (Černý, 1990, personal communication). Drought induced infection by fungi which reduce absorbing surfaces in root

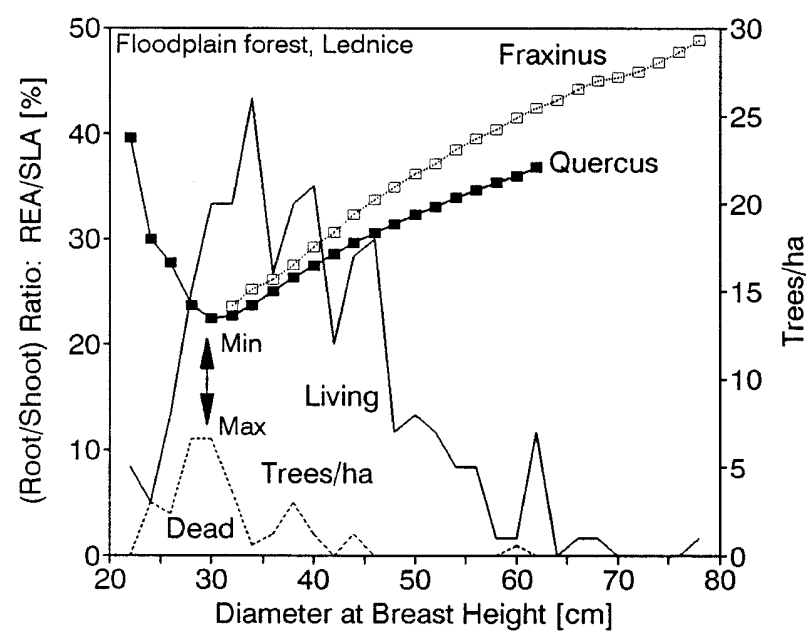

Figure 6. Tree mortality associated with unfavorable root/shoot ratio. "Root/shoot" ratio on the whole (large) tree level was expressed as the ratio of "Root enveloping area/Solar equivalent leaf area". This is compared to the density of living and dead trees (= mortality over the period of 20 years) in the experimantal floodplain forest (site Horni les, forest district Breclav), southern Moravia. Critical values are marked by arrows. systems and caused increasing mortality (see figure 6) also leads to significant lowering the mechanical stability of forests. Trees with heavily decomposed roots, typically with the coarse roots rotten from their tops down to the distance only slightly longer then stem diameter (about $1.6 \times \mathrm{DBH}$ ) from tree trunks easily fell down under any minor atmospheric perturbations (as wind or rain). Impaired root system of such trees (even if there are no visible symptoms) was clearly reflected by significantly lowering sap flow [9].

Under conditions of limited water supply transpiration may decrease theoretically in all trees by the same proportion or less in some trees and more in others. According to the same principle, in some trees transpiration can be reduced to a low level, which does not allow them to survive. When these trees die, more free space in the soil (larger portion of stand area to accept precipitation and/or underground water) will remain available for other neighbor trees, which will improve their situation (this is the principle of artificial control of tree water supply through modification of stand density, i.e., thinning). Results of water balance on the level of both stands and individual trees can be further applied to estimate an acceptable stand density under certain environmental conditions and eventually predict (or prevent) mortality after their significant changes.

\section{CONCLUSIONS}

1. In forest stands growing on heavy soils and adapted to ample underground water supply (where tree root systems do not occupy the soil completely), it may be useful to consider two compartments when calculating the stand water balance: rooted volume (subjected to higher depletion of water) and root-free (supplementary or "storage") volume of soil, connected by the horizontal transport of water.

2. Under non-limiting underground water and mild weather (low potential evapotranspiration) transpiration of forest trees is fully supplied by net precipitation. Under dry weather, net precipitation supplied only a fraction of water for actual evapotranspiration and trees need to extract most of their water demands for transpiration (up to 70\%) from the underground water table, and a significant portion of water from that present in the supplementary soil volume.

3. Under theoretical conditions of no underground water supply, actual evapotranspiration must be reduced at least to the level that would assure that all the water required for evapotranspiration will be present in the system, even for conditions of mild weather. Under dry 
weather it will be reduced more dramatically and may fall below a level critical for tree survival.

4. Soil hydraulic conductivity is one of the most important limiting factors for plant water supply. Usual parameters as the soil water content or soil water potential are insufficient to explain the plant water supply, especially on heavy soils under non-saturated conditions.

5. Local drought can occur in heavy soils under relatively high soil water content, usually close to their field water capacity. This may cause misunderstanding when interpreting soil water data in terms of tree behavior, especially when in practice the water content is measured at a certain distance from absorbing root surfaces.

6. Suppressed trees with less developed root systems and those which root systems are damaged by fungi cannot absorb sufficient water due to smaller absorbing surfaces, what is easily visible on their low sap flow. Such trees are less mechanically and functionally stable and show higher mortality.

Acknowledgements: The authors express their best thanks to Dipl. Ing. Jiri Kučera, Environmental Measuring Systems, Brno, for his excellent help with the sap flow measurement. The study was supported by EU grant No.ERBEV5V-CT94-0468 and CS grant VS 96077.

\section{REFERENCES}

[1] Ambros Z., Water balance of forest stands in the Carpathians (in Slovak), Lesnictvi-Forestry 24 (1978) 203-221.

[2] Aruga M., Nakamura F., Kikuchi S., Yajima T., Characteristics of floodplain forests and their site conditions in comparison to toeslope forests in the Tokachi river, J. Jpn. For. Soc. 78 (1996) 354-362.

[3] Ayres P.G., Water relations of diseased plants, in: Water deficits and plant growth, Vol. V, Academic Press, New York, San Francisco, London, 1978, pp. 1-60.

[4] Č ermák J., Short- and long-term response of transpiration flow rate in full-grown trees to water stress, in: Proc. 18th IUFRO World Congress, Whole-Plant Physiology Working Party (S 2.01-15), 7-21 September 1986, Ljubljana, 1986, pp. 187-193.

[5] Čermák J., Solar equivalent leaf area as the efficient biometrical parameter of individual leaves, trees and stands, Tree Physiol. 5 (1989) 269-289.

[6] Č ermák J., Leaf distribution in large trees and stands in floodplain forest of southern Moravia, Tree Physiol. 18 (1998) 727-737.

[7] Čermák J., Kučera, J., The compensation of natural temperature gradient in the measuring point during the sap flow rate determination in trees, Biol Plant (Praha) 23 (1981) 469-471.
[8] Čermák J., Kučera J., Scaling up transpiration data between trees, stands and watersheds, Silva Carelica 15 (1990) $101-120$

[9] Čermák J., Kučera J., Changes in transpiration of healthy mature trees due to environmental conditions and of those with damaged water conductive system, in: Klimo E., Materna J. (Eds.), Proc. Cs.MAB Natl. Comm./IUFRO Internat. Workshop, Verification of hypotheses and possibilities of recovery of forest ecosystems, 4-8 September 1989, Beskydy Mt., Agr. Univ. Brno., 1990, pp. 275-286.

[10] Čermák J., Deml M., Penka M., A new method of sap flow rate determination in trees, Biol Plant (Praha) 15 (1973) 171-178.

[11] Čermák J., Ulehla J., Kučera J., Penka M., Sap flow rate and transpiration dynamics in the full-grown oak (Quercus robur L.) in floodplain forest exposed to seasonal floods as related to potential evapotranspiration and tree dimensions, Biol Plant (Praha) 24 (1982) 446-460.

[12] Čermák J., Kučera J., Stepankova M., Water consumption of full-grown oak (Quercus robur L.) in a floodplain forest after the cessation of flooding, in: Penka M., Vyskot M., Klimo E., Vasicek F. (Eds.), Floodplain forest ecosystem II, Dev. Agric. Mana. For. Ecol. 15B, Elsevier, Amsterdam, Oxford, New-York, Tokyo, 1991, pp. 397-417.

[13] Čermák J., Kučera J., Extremely fast changes of xylem water flow rate in mature trees, caused by atmospheric, soil and mechanical factors, in: Raschi A., Borghetti M. (Eds.), Proc. CEC Internat. Workshop, Methodologies to assess the impacts of climatic changes on vegetation: analysis of water transport in plants and cavitation of conduits, 29-31 May 1991, Florence, 1991, pp. 181-190.

[14] Čermák J., Michalek J., Selection of sample trees in forest stands using the "quantiles of total" (in Czech), Lesnictvi 37 (1991) 49-60.

[15] Čermák J., Matyssek R., Kučera J., Rapid response of large, drought stressed beech trees to irrigation, Tree Physiol. 12 (1993) 281-290.

[16] Č ermák J., Kravka M., Krejzar T., Kučera J., Studies of revitalization of floodplain forests in southern Moravia. I. Transpiration of floodplain forest in Lednice during periods with no natural and artificial floods (in Czech), Res. Rep. Inst. For. Ecol., Mendel Univ. Brno for the Ministry of Agriculture and the Forest Enterprise of Czech Republic in Zidlochovice, 1995, $20 \mathrm{p}$.

[17] Č ermák J., Cienciala E., Kučera J., Lindroth A., Bednarova E., Individual variation of sap flow rate in large pine and spruce trees and stand transpiration: A pilot study at the central NOPEX site, J. Hydrol. 168 (1995) 17-27.

[18] Čermák J., Hruska J., Martinkova M., Prax A., City tree roots and survival near houses analyzed using sap flow and ground penetrating radar technique, Plant and Soil 219 (2000) $103-115$

[19] Cienciala E., Kučera J., Lindroth A., Čermák J., Grelle A., Halldin S., Canopy transpiration from a boreal forest in Sweden during a dry year, Agric. For. Meteorol. 86 (1997) 157-167. 
[20] Collective, Elements of the legend for the soil map of Europe at scale 1:1000000, FAO, Rome, 1970.

[21] Dister E., Flood tolerance of floodplain forest trees on loamy sites (in German), Verhandlungen der Gesselschaft fur Okologie 10 (1983) 325-336.

[22] Herbst M., Eschenbach K., Kappen L., Water use in neighbouring stands of beech (Fagus sylvatica L.) and black alder (Alnus glutinosa (L.) Gaertn.), Ann. For. Sci. 56 (1999) 107-120.

[23] Hughes F.M.R., The influence of flooding regimes on forest distribution and composition in the Tana river floodplain, Kenya, J. Appl. Ecol. 27 (1990) 475-491.

[24] Joffre R., Rambal S., How tree cover influences the water balance of Mediterranean rangelands, Ecology 74 (1993) $570-582$.

[25] Korpel St., Growth, production and form of individual trees (in Czech), in: Vyskot M. (Ed.), Zaklady rustu a produkce lesu, SZN, Praha, 1971, pp. 157-213.

[26] Krontorad K. Water regime and ecologically important physical properties of semigley soils under the floodplain forest of southern Moravia, in: Ecosystem study on floodplain forest in southern Moravia, Czechoslovak IBP Report No. 4, Univ. Agric. Brno, 1974, pp. 329-337.

[27] Kučera J., Č ermák J., Penka M., Improved thermal method of continual recording the transpiration flow rate dynamics, Biol Plant (Praha) 19 (1977) 413-420.

[28] Linder S., Axelsson B., Changes of carbon uptake and allocation patterns as a result of irrigation and fertilization in a young Pinus sylvestris stand, in: Waring R.H. (Ed.), Carbon Uptake and Allocation in Subalpine Ecosystems as a Key to Management, Univ. Oregon, Corvallis, Oregon, 1982, pp. 38-44.

[29] Lozek V., Nature in quarternary period (in Czech), Priroda ve ctvrtohorach, National Agric. Publ. House, SZN Praha, 1973, $350 \mathrm{p}$.

[30] Mooney H.A., Winner W.E., Carbon gain and growth as affected by atmospheric pollutants., in: Schulte-Hostede S., Darral N.M., Blank L.W., Wellburn A.R. (Eds.), Air pollution and plant metabolism, Elsevier, London, New-York, 1988, pp. 272-287.

[31] Nemec J., Hydrology (in Czech), National Agric. Publ. House, SZN, Prague, 1965, 240 p.

[32] Pallardy S.G., Čermák J., Ewers F.W., Kaufmann M.R., Parker W.C., Sperry J.S., Water transport dynamics in trees and stands, in: Smith P.G., Hinckley T.M. (Eds.), Resource physiology of conifers-acquisition, allocation and utilization, Academic Press, San Diego, New-York, Boston, London, Sydney, Tokyo, Toronto, 1995, pp. 301-389.

[33] Pelisek J., The dynamics of ecological soil properties in floodplain forest of south Moravia (Lednice) under the impact of water management (in Czech), in: Proc. Funkce, produktivita a struktura ekosystemu luzniho lesa, Publ.VSZ Brno, 1975.

[34] Penka M., Čermák J., Stepanek V., Palat M., Diurnal courses of transpiration rate and transpiration flow rate as determined by the gravimetric and thermometric methods in a full-grown oak tree (Quercus robur L), Acta Univ. Agric. (Brno) Ser C 48 (1979) 3-30.

[35] Penka M., Čermák J., Prax A., Ulehla J., Zidek V., Water consumption of oak (Quercus robur L.) in the alluvium of the Dyje river in non-limiting moisture conditions (in Czech), Lesnictvi-Forestry 29 (1983) 481-496.

[36] Pivec J., A comparison of actual evapotranspiration of a floodplain forest in S. Moravia six and 15 years after regular floods (in Czech), Lesnictvi 39/5 (1993) 187-191.

[37] Prax A., The hydrophysiological properties of the soil and changes in them, in: Penka M., Vyskot M., Klimo E., Vasicek F. (Eds.), Floodplain Forest Ecosystem II, Elsevier, Amsterdam coed. Academia, Prague, 1991, pp. 145-168.

[38] Prax A., Palat M., Soil moisture regime of SouthMoravian floodplains (in German), Arch. Hydrobiol. Suppl. 101, Large Rivers 9 (1995) 513-523.

[39] Putz F.E., Parker G.G., Archibald R.M., Mechanical abrasion and intercrown spacing, Am. Midl. Nat. 112 (1984) 24-28.

[40] Rakhmanov V.V., Hydroclimatic role of forests (in Russian), Leshnaya promyshlennost, Moscow, 1984, 240 p.

[41] Riedacker A., Rythmes de croissance et de régénération des racines des végétaux ligneux, Ann. Sci. For. 33 (1976) 109-138.

[42] Schoeneweiss D.F., Water stress as a predisposing factor in plant disease, in: Water deficits and plant growth, Vol. V, Academic Press, New-York, San Francisco, London, 1978, pp. 61-90.

[43] Schulze E.-D., Chapin F.S., Plant specialization to environments of different source availability, Ecol. Stud. 61 (1987) 120-148.

[44] Uhrecky I., Smolik Z., Havlicek V., Mrkva R., Radiation, temperature and rainfall regimes of the floodplain forest ecosystem, in: Penka M., Vyskot M., Klimo E., Vasicek F. (Eds.), Floodplain forest ecosystem I, Elsevier, Amsterdam coed. Academia, Prague, 1985, 33-51.

[45] Vasicek F., Shrub layer in the ecosystem of floodplain forest (in Czech), Res. Rep. VI-2-1/B, Univ. Agr. Brno., 1975.

[46] Vasicek F., Natural conditions of floodplain forests, in: Penka M., Vyskot M., Klimo E., Vasicek F. (Eds.), Floodplain Forest Ecosystem 1, Elsevier, Amsterdam coed. Academia, Prague, 1985, pp. 13-29.

[47] Vyskot M., Tree story biomass in lowland forest in south Moravia, Rozpravy CSAV 86 Publ. Academia, Praha, $1976,166 \mathrm{p}$

[48] Wendelberger G., Heavy-hardwood forest subject to (regular) flooding: a contribution to the ecology of the Central European floodplain forest, Vegetatio 5-6 (1973) 253-281.

[49] Xian-Huan Wen, Gomez-Hernandez J.J., Upscaling hydraulic conductivities in heterogenous media: An overview, J. Hydrol. 183 (1996) 9-32.

[50] Zidek V., Actual and potential evapotranspiration in the floodplain forest, Ekologia 7 (1988) 43-59. 